DOI 10.18551/rjoas.2021-12.10

\title{
BUSINESS MODEL EVALUATION OF PRIVATE ELEMENTARY SCHOOL IN INDONESIA
}

\author{
Dafina Risty Rahma*, Fahmi Idqan, Hasanah Nur \\ School of Business, IPB University, Bogor, Indonesia \\ *E-mail: ristydafina@gmail.com
}

\begin{abstract}
The decline in SDS Kartini students continues to disrupt the learning process. The COVID-19 Pandemic has caused SDS Kartini to adapt to the current situation. It requires SDS Kartini to know the business model to continue school activities. The aims of this study are (1) to analyze the current business model, (2) to evaluate the business model, and (3) to design a new business model for SDS Kartini. This study uses a business model canvas and importance-performance analysis methods. The results showed that all elements of the business model were identified. Evaluation of the business model with importanceperformance analysis resulted in elements that became priority improvements, namely channels and key resources. The new business model is designed based on the results of priority improvements. Improvement of channels, namely creating online and offline marketing media. Improvement of key resources, adding online and offline school facilities, and increasing the ability of teachers and educators in digital learning. Modifications to these elements affect changes to customer relationships, revenue streams, and customer segments that are not improved and developed because they are in the high performance, low importance quadrant.
\end{abstract}

\section{KEY WORDS}

Business model canvas, elementary school, importance-performance analysis.

Indonesia education taken mainly by the community is elementary school because it is the initial level of formal education. Elementary school (SD) aims to contribute to the implementation of public education. Elementary schools are organized by the government and the private sector so that they are divided into Public Elementary Schools and Private Elementary Schools. The participation and contribution of the private sector in the provision of education in Indonesia are pretty diverse, ranging from primary education to higher education. Elementary schools in Indonesia have developed quite well every year. The number of primary schools in Indonesia in the $2020 / 2021$ academic year is 160,697 schools consisting of 140,637 public elementary schools and 20,060 private elementary schools (Badan Pusat Statistik, 2020; Marini, 2016).

The development of elementary schools in Indonesia is influenced by the number of schools from various provinces in Indonesia. Elementary schools with the highest number of schools tend to be in areas with the largest population. North Sumatra has the most significant proportion of private elementary schools compared to other provinces in the $2020 / 2021$ academic year, with 10,464 consisting of 8,768 elementary schools and 1,696 elementary schools, with the most significant proportion of SDS in Indonesia (Kementerian Pendidikan dan Kebudayaan 2021).

A private elementary school are organized by a foundation or educational institution. Based on Law No. 28 of 2004, a foundation is a legal entity or institution that aims to fulfill goals in the social sector. Educational foundations play a role in helping education by offering various levels of education ranging from Kindergarten to Higher Education. The educational foundation must be used optimally to play a role in the nation's intellectual life by the 1945 Constitution (Gazali, 2013). Kartini Medan Foundation is one of the organizers of Private Elementary Schools in Medan, North Sumatra. This educational foundation was founded in 1970. The Kartini Medan Foundation organizes kindergarten and elementary school education. 
Indonesia is currently being hit by a virus caused by the coronavirus disease 2019 (COVID-19). The World Health Organization has designated COVID-19 as a pandemic because it has spread widely in all countries in the world (Kementerian Kesehatan 2020). To prevent the spread of COVID-19, the Government of Indonesia has implemented restrictions on all community activities. This activity restriction is detrimental to almost all industries, one of which is the education industry. The COVID-19 Pandemic has changed the learning system in Indonesia. The teaching and learning process in education has turned into online learning. These changes require adjustments for all elements of education because they occur quickly. Teachers, students, and parents are needed in implementing online schools because teachers have difficulty providing material and supervising students. It interferes with the learning process. Online learning also requires facilities and infrastructure to support learning objectives (Putri et al., 2020; Sari et al., 2021).

The COVID-19 Pandemic has harmed SDS Kartini by decreasing the number of students and disrupting the learning process. If the teaching and learning process is interrupted for a long time, it will cause a decrease in the quality of education (Alawiyah, 2017). The decline in the quality of education will impact the assessment or perception of society, especially parents of students on SDS Kartini, because each parent has a vital role in determining school selection (Fitriana \& Triwiyanto, 2016). It is a challenge for SDS Kartini so that people have a good perception in assessing and choosing schools at SDS Kartini. Due to the unresolved pandemic conditions and the continuous decline in students, SDS Kartini had to adapt and evaluate the business model to compete and develop. Based on this description, the objectives of this research are (1) to analyze the current business model, (2) to evaluate the business model, and (3) to design a new business model for SDS Kartini.

\section{METHODS OF RESEARCH}

This research was conducted at an elementary school belonging to the Kartini Medan Foundation, Medan, in February-December 2021. This research is a descriptive study with qualitative and quantitative approaches. This study uses primary and secondary data. Primary data were obtained through interviews, distributing questionnaires, and observation. Secondary data in this research comes from literature review, the internet, and related reports and documents.

Respondents in this study were categorized into internal and external respondents. The sample of internal respondents is determined using a judgment sampling approach, where respondents are chosen intentionally by considering their expertise in their field. Meanwhile, external respondents were determined using a convenience sampling approach, where respondents were selected by considering the ease of reach and the exact time the respondents were (Amirullah, 2015). The internal respondents consisted of the head of the foundation, the principal, and the teachers of SDS Kartini, while the external respondents consisted of parents and local communities. The number of external respondents is determined by the minimum number of respondents using the survey method is 30 people, so the total number of external respondents is 60 (Supranto, 2001).

Data processing techniques contain an overview of how to process data to obtain results using analytical methods (Hardani et al., 2020). This study uses a combination of Business Model Canvas (BMC) and Importance-Performance Analysis (IPA).

Business model analysis was conducted using the business model canvas (BMC). BMC is used to analyze the current business model of SDS Kartini. BMC is the most complex, analytical, flexible, and general business model visualization tool for research in all industries. BMC consists of nine customer segments, value propositions, channels, customer relationships, revenue streams, key resources, key activities, key partnerships, and cost structure. A business model aims to identify systems, trends, and changes. Business models can also help SDS Kartini develop competitive advantages that they can detect. However, the business model can not only be used for profit-oriented companies. A much broader application of business models and meaningful concepts is widely used concerning public 
sector administration, NGOs, schools or universities, and individuals (Nielsen \& Lund, 2018; Osterwalder \& Pigneur, 2013; Slávik \& Bednár, 2014; Teece, 2010).

Business model evaluations are carried out using Importance-Performance Analysis (IPA), which aims to assess and measure the relationship between customers' level of interest (expectations) and the performance of SDS Kartini. The IPA matrix consists of four quadrants, namely Quadrant I (high importance, low performance), Quadrant II (high importance, high performance), Quadrant III (low importance, low performance), Quadrant IV (low importance, high performance). The IPA method is carried out to determine priorities for improving business model elements by SDS Kartini external respondents (Martilla \& James, 1977; Matzler et al., 2004).

The last analysis carried out is the design of a new business model resulting from the evaluation of the business model. Many previous researchers used importance-performance analysis to develop and improve business models. The results of the analysis can indicate elements that must be changed. A business model design is based on priorities for improving business model elements (Viali et al., 2018; Widyastuti et al., 2019). The framework of thought in this research can be seen in Figure 1.

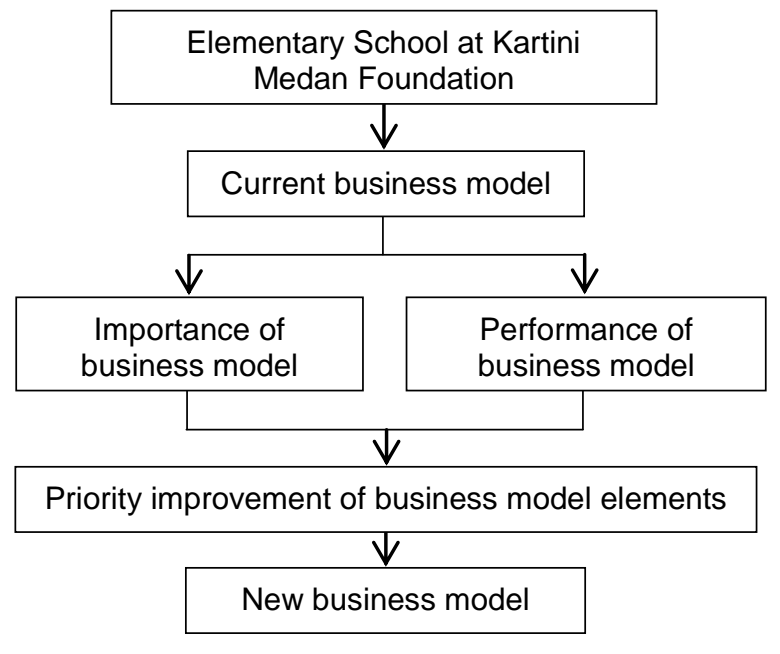

Figure 1 - Study Framework

\section{RESULTS AND DISCUSSION}

SDS Kartini is a private elementary school owned by the Kartini Medan Foundation, which had an establishment permit in 1970. SDS Kartini is led by a school principal supervised directly by the foundation's head. SDS Kartini has 12 teachers and teaching staff supporting the learning process: the principal, vice-principal, treasurer, administration, librarian, class teacher, and subject teacher. In the 2020/2021 academic year, 94 students at SDS Kartini consist of 46 female and 48 male students. Currently, SDS Kartini has B accreditation and uses the 2013 curriculum in the learning process, which is held in the morning starting at 07.00-12.00 WIB from Monday-Saturday.

Analysis of the business model using the business model canvas framework consists of nine interrelated elements to provide an overview of the current condition of SDS Kartini.

The customer segment describes the customers that SDS Kartini wants to reach. SDS Kartini's current customer segment comprises students, parents, and the Medan Area District public. Parents are included in the customer segment because parents have an essential role in determining and choosing schools for their children. Students who are currently customers of SDS Kartini, on average, live in the same sub-district. People who want to enroll in school have a minimum age requirement of six years. Currently, there are 94 students at SDS Kartini in the 2021/2022 academic year, consisting of 48 male students and 46 female students.

The value proposition describes services that can create value and meet customer needs. The value proposition offered by SDS Kartini to customers is in the form of learning 
services according to the applicable curriculum. The curriculum used today follows elementary schools in general, namely K-13. In addition, SDS Kartini also prioritizes character, religion, and skill education for students. Although SDS Kartini is a public school, SDS Kartini provides religious learning. SDS Kartini also is a public elementary school based on Islam. If students experience academic and non-academic problems, SDS Kartini also offers guidance and consulting services for students in need.

The channel describes how SDS Kartini communicates as a liaison with customers. SDS Kartini's channels consist of social media and print media. SDS Kartini uses social media such as Facebook, Instagram, and WhatsApp to provide information to customers. SDS Kartini also communicates directly or through communication media with parents to avoid misunderstandings in delivering information. Channels on SDS Kartini are also used as a marketing medium. In doing marketing to get customers, SDS Kartini uses print media, especially brochures. Brochures are usually distributed to parents and the surrounding community in the new school year.

Customer relationship describes the relationship that SDS Kartini builds with its customers. SDS Kartini forms committees, establishes brotherly relationships, and provides mutual feedback between schools and parents to create and maintain customer relationships. The establishment of the school committee aims to increase the participation of parents in the implementation of school activities. SDS Kartini also establishes a brotherly connection with parents hoping that parents will feel comfortable sending their children to SDS Kartini. Parents and SDS Kartini give each other feedback. This collaboration between parents and the school is expected to make educating and providing learning to students easier. Feedback from parents of students to the school is input to improve and improve the quality of services.

e) Revenue Streams

The income stream describes SDS Kartini's income to run the business model. Currently, SDS Kartini's revenue mainly comes from tuition paid by students. The tuition fee is set at IDR 115,000 that can be delivered directly and installment for underprivileged students. In addition to income from school fees, SDS Kartini also receives school operational assistance funds (BOS funds). These funds are obtained based on the number of students and needs. Another financial assistance received by SDS Kartini comes from individual donors or groups of people who are not permanent.

The key resources describe the critical assets required for the business model to work well. The primary resources at SDS Kartini are school facilities and teachers, and teaching staff. School facilities consist of facilities and infrastructure needed to support the learning process. The facilities required are school buildings, classrooms, teacher rooms, libraries, learning media, and other supporting facilities. The learning media in question are equipment teachers and students need in the learning process, such as books and stationery. Textbooks are given to students based on the assistance received from the BOS Fund. In addition, the services of teachers and teaching staff are no less important than school facilities. Teachers and educators must have good teaching skills to convey the material learned to students.

The key activities describe the essential activities carried out by SDS Kartini so that the business model can work. The main activity of SDS Kartini is learning activities. The applicable K-13 curriculum carries out learning activities. In addition to the main activities, there are supporting activities such as student activities, teacher and educator training exercises, and activities involving parents. Student activities (extracurricular) provided by SDS Kartini are scouting, swimming, dance, computers, nasyid, and taekwondo. In supporting learning activities, it is necessary to renew knowledge by teachers and educators. Therefore SDS Kartini involves teachers and educators in academic and non-academic training activities such as literacy training, scout coaching, and dance arts. SDS Kartini did not forget to invite parents to participate in school activities.

Main partners describe partners who support and work with SDS Kartini to run the business model. The main partners of SDS Kartini are the Government, donors, the Kartini Medan Foundation, teachers and educators, and parents of students. The government plays a role in assisting the operation of SDS Kartini by providing BOS funds. Donors also provide financial assistance for the process of SDS Kartini, although it is not permanent. The critical 
partner who fully supports all SDS Kartini activities is the Kartini Medan Foundation. Every activity carried out is always under the supervision and support of the foundation. Parents also have an essential role in working together to help and support the students' learning process.

The cost structure describes the costs incurred by SDS Kartini to run the business model. The costs incurred by SDS Kartini regularly are the salaries of teachers and educators, school maintenance costs, student activity costs, and costs for training teachers and educators. The salaries of teachers and educators are an obligation that must be paid every month. It is crucial to maintain and maintain school facilities in the learning process to become a routine expense issued by SDS Kartini every month. Student activities also require money, but these costs are incurred by SDS Kartini and try not to involve parents. Another cost is the cost of training teachers and educators. However, these costs are not always incurred every month, but when the training is held.

\begin{tabular}{|c|c|c|c|c|c|}
\hline \multirow[t]{2}{*}{$\begin{array}{l}\text { Key } \\
\text { Partners } \\
\text { - Government } \\
\text { - Donors } \\
\text { - Kartini Medan } \\
\text { Foundation } \\
\text { - Teachers and } \\
\text { educators } \\
\text { - Parents }\end{array}$} & $\begin{array}{l}\text { Key } \\
\text { Activities } \\
\text { - Learning activities } \\
\text { - Student activities } \\
\text { (extracurricular) } \\
\text { - Teacher and } \\
\text { educator training } \\
\text { activities } \\
\text { - Activities with } \\
\text { parents }\end{array}$ & \multirow{2}{*}{\multicolumn{2}{|c|}{$\begin{array}{l}\text { Value } \\
\text { Propositions } \\
\text { - Curriculum } \\
\text { learning-13 } \\
\text { - Character, } \\
\text { religion, and skills } \\
\text { education } \\
\text { - Academic } \\
\text { guidance and } \\
\text { consultation }\end{array}$}} & $\begin{array}{l}\text { Customer } \\
\text { Relationships } \\
\text { - School committee } \\
\text { - Family relationship } \\
\text { with parents } \\
\text { - Feedback between } \\
\text { parents and school }\end{array}$ & \multirow[t]{2}{*}{$\begin{array}{l}\text { Customer } \\
\text { Segments } \\
\text { - Student } \\
\text { - Parents } \\
\text { - Medan Area } \\
\quad \text { Districts }\end{array}$} \\
\hline & $\begin{array}{l}\text { Key Resources } \\
\text { - School facilities } \\
\text { (Classrooms, } \\
\text { libraries, ICT } \\
\text { rankings, books, } \\
\text { stationery, etc.) } \\
\text { - Teachers and } \\
\text { educators }\end{array}$ & & & $\begin{array}{l}\text { Channels } \\
\text { - Social media } \\
\text { (Facebook, } \\
\text { Instagram, and } \\
\text { WhatsApp) } \\
\text { - Print media } \\
\text { (Brochure) }\end{array}$ & \\
\hline \multicolumn{3}{|c|}{$\begin{array}{l}\text { Cost Structure } \\
\text { - Salaries of teachers and educators } \\
\text { - School maintenance costs } \\
\text { - } \quad \text { Cost of student activities (extracurricular) } \\
\text { - } \quad \text { Teacher training costs }\end{array}$} & \multicolumn{2}{|c|}{$\begin{array}{ll}\text { Revenue Streams } \\
\text { - } \quad \text { Tuition fee } \\
\text { - } \quad \text { BOS fund } \\
\text { - } \quad \text { Fixed assistance }\end{array}$} & \\
\hline
\end{tabular}

Figure 2 - A business model canvas of SDS Kartini

The business model that has been identified is then analyzed for the level of importance and performance on nine BMC element blocks using importance-performance analysis (IPA). This analysis aims to determine the priority of business model development. The average value of importance and performance was measured and projected using a four-quadrant diagram. This measurement aims to determine the BMC elements that are a priority for improvement. The BMC elements that have been improved are those in quadrant I, which has the highest gap between performance and importance.

Table 1 - Importance-performance analysis of SDS Kartini

\begin{tabular}{|c|l|c|c|c|}
\hline No. & \multicolumn{1}{|c|}{ Variable } & Importance & Performance & Gap \\
\hline 1. & Customer Segments & 4,01 & 3,93 & $-0,08$ \\
\hline 2. & Value Propositions & 3,89 & 4,31 & 0,42 \\
\hline 3. & Channels & 3,58 & 4,34 & 0,76 \\
\hline 4. & Customer Relationships & 3,83 & 4,12 & 0,29 \\
\hline 5. & Revenue Streams & 3,93 & 4,03 & 0,10 \\
\hline 6. & Key Partners & 3,97 & 4,27 & 0,30 \\
\hline 7. & Key Activities & 3,83 & 4,27 & 0,44 \\
\hline 8. & Key Resources & 3,66 & 4,28 & 0,62 \\
\hline 9. & Cost Structure & 3,63 & 4,17 & 0,54 \\
\hline \multicolumn{2}{r}{ Mean } & 4,19 & 3,81 & 0,37 \\
\hline
\end{tabular}




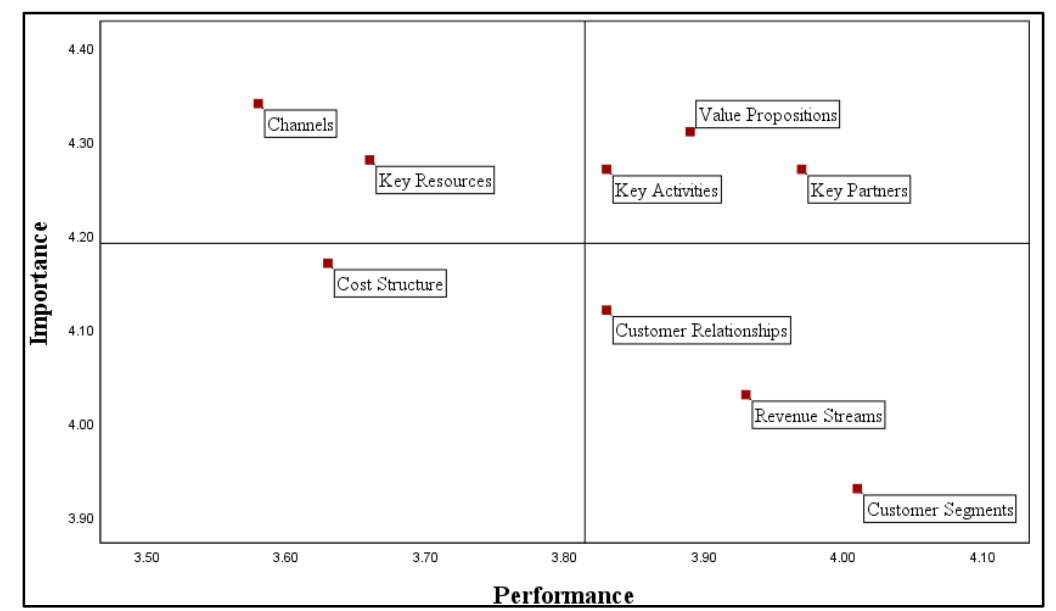

Figure 3 - Quadrant importance and performance of BMC SDS Kartini

Based on the picture above, BMC elements are considered to have a high level of importance, but the performance provided is not optimal. Quadrant I contains priority elements for improvement, namely (1) channels, which have the highest importance and lowest performance levels among the nine BMC elements. It shows that the community is not satisfied with the current performance of SDS Kartini channels and wants a better chance, and (2) Key Resources, where this element has the second largest gap after channels. The performance of key resource elements owned by SDS Kartini is still considered low but has a high level of importance. SDS Kartini must develop key resources to improve performance according to the community's interests.

Quadrant I. This quadrant shows that the BMC element is considered to have a high level of importance, but at this time, the performance provided is not optimal. Quadrant I contains priority elements for improvement, namely channels and key resources.

a) Channels. Channels are considered to have the highest importance and lowest level of performance among the nine BMC elements. Respondents are not satisfied with the current performance of SDS Kartini channels and want changes for the better. Respondents considered that SDS Kartini was not very active in providing information through their existing social media. SDS Kartini also only distributes brochures for the new school year, considered ineffective enough to market schools.

b) Key Resources. This element has the second largest gap after channels. According to the respondents, the performance of the key resource elements owned by SDS Kartini is still considered low but highly important. SDS Kartini must develop key resources to improve performance according to respondents' interests. Respondents believed that the current school facilities had not met all teaching and learning needs. SD Kartini has a relatively small classroom size, not by Government standards. Other supporting facilities are also inadequate, such as classroom furniture and ICT equipment.

Quadrant II. Quadrant II shows that all BMC elements have a high level of performance and importance. This quadrant consists of value propositions, key partners, and key activities.

a) Value Propositions. Value propositions are one of the essential elements in BMC. This element has a high level of performance and importance. It shows that the respondent assesses this element according to their interests. However, even though it has good performance, it can still be improved to support other elements.

b) Key Partners. The key partner's element has the second-highest level of performance. According to the respondents, the story of importance in this element is also relatively high. It indicates that elements must be maintained to support other elements related to key partners.

c) Key Activities. According to the respondent's assessment, this element has a high level of performance and importance. It shows that the key activities of SDS Kartini must be 
maintained but can be developed if needed to support the elements included in the priority quadrant.

Quadrant III. This quadrant indicates that the BMC element has a low level of performance and importance. Components in this quadrant must be controlled and monitored because of the possibility that respondents' interests may change so that it is necessary to improve their performance. The element that is included in Quadrant III is the cost structure.

The cost structure is an element that is considered an element with a low level of performance and importance. It shows that respondents consider this element not very important. However, if the implementation of this element is improved, it will be better for SDS Kartini.

Quadrant IV. Quadrant IV shows that each BMC element has a high level of performance but with a low level of importance. This quadrant has three components: customer relationships, revenue streams, and customer segments.

a) Customer Relationships. This element is an element that has a high level of performance and a low level of importance. It shows that respondents think that the SDS Kartini customer relationship is not very important and is considered excessive in its implementation.

b) Revenue Streams. The revenue stream element has a high level of performance with low importance. It shows that respondents have no interest in SDS Kartini's revenue stream, but this element has a good performance.

c) Customer Segments. Customer segments are elements with the highest level of performance and the lowest level of performance. This element has the smallest gap compared to other elements. It shows that respondents do not consider the customer segments of SDS Kartini important.

New Business Model. The improvement of the priority business model using scientific analysis shows elements with high importance and low performance, namely the main channels and resources. The design of this new business model was carried out to equalize the internal and external interests of SDS Kartini. Improvement and development of the main channel and resource elements affect the changes of other elements. However, customer relationships, revenue streams, and customer segments have not changed. The element is in quadrant IV, which means it has a high level of performance with low importance so that there is no improvement and development on that element.

a) Improvement of channels. SDS Kartini's channels contain media used for marketing and communication. Improvements to be made are grouping channels into online and offline. SDS Kartini's social media use on online channels is limited, so it needs to be used properly. According to research by Hootsuite and We are social, active users of social media are 170 million people, which means $61.8 \%$ of the total population of Indonesia in 2021. Indonesian people's most widely used social media are YouTube, WhatsApp, Instagram, Facebook, and Twitter (Kemp 2021). It can be used as an opportunity by utilizing social media widely used by the community to promote and convey information related to SDS Kartini. Although marketing uses social media a lot, marketing through print media is still needed. The offline channel will consist of word-of-mouth marketing and print media, which can be done by making advertisements, banners, brochures, and business cards. However, marketing with print media requires costs that will increase expenses.

b) Improvement of key resources. Elements of SDS Kartini's key resources consist of school facilities and services for teachers and educators. School facilities are comprised of facilities and infrastructure, which are currently still very limited. Improvements to school facilities will be divided into online and offline schools. The online facilities needed are ICT devices, internet networks, and online learning platforms. Currently, offline learning support facilities have not been appropriately fulfilled. Renewal of facilities such as old tables, chairs, and blackboards is needed. The classrooms and teachers' rooms are also not well equipped. It is necessary to repair and procure infrastructure to improve SDS Kartini facilities. Furthermore, according to the respondents, teacher and educators' service attributes are still unsatisfactory. Based on the priority, it is necessary to increase the competence of teachers 
and educators through seminars and training on the use of information technology, especially ICT and the use of online learning platforms. SDS Kartini must include teachers in digital learning workshops and training to compete with other schools. If there is a teacher recruitment process later, the foundation can choose teachers with better competencies.

\begin{tabular}{|c|c|c|c|c|}
\hline \multirow[t]{2}{*}{$\begin{array}{l}\text { Key } \\
\text { Partners } \\
\text { - Government } \\
\text { - Donors } \\
\text { - Kartini Medan } \\
\text { Foundation } \\
\text { - Teachers and } \\
\text { educators } \\
\text { - Parents } \\
\text { - Alumni }\end{array}$} & $\begin{array}{l}\text { Key } \\
\text { Activities } \\
\text { - Learning activities } \\
\text { - Student activities } \\
\text { (extracurricular) } \\
\text { - Training activities } \\
\text { (digital education) for } \\
\text { teachers and educators } \\
\text { - Activities with parents } \\
\text { - Marketing activities } \\
\text { - Activities with alumni }\end{array}$ & \multirow{2}{*}{$\begin{array}{l}\text { Value } \\
\text { Propositions } \\
\text { - Curriculum } \\
\text { learning-13 and } \\
\text { adding } \\
\text { supporting } \\
\text { lessons } \\
\text { - Character, } \\
\text { religion, and } \\
\text { skills education } \\
\text { - Academic } \\
\text { guidance and } \\
\text { consultation } \\
\text { - Digital learning } \\
\text { using various } \\
\text { platforms }\end{array}$} & $\begin{array}{l}\text { Customer } \\
\text { Relationships } \\
\text { - School committee } \\
\text { - Family relationship } \\
\text { with parents } \\
\text { - Feedback } \\
\text { between parents } \\
\text { and school }\end{array}$ & \multirow[t]{2}{*}{$\begin{array}{l}\text { Customer } \\
\text { Segments } \\
\text { - Student } \\
\text { - Parents } \\
\text { - Medan Area } \\
\text { Districts }\end{array}$} \\
\hline & $\begin{array}{l}\text { Key Resources } \\
\text { - School facilities } \\
\text { (Online) } \\
\text { - ICT devices } \\
\text { (computers, laptops, } \\
\text { smartphones) } \\
\text { - Internet (Wi-Fi and } \\
\text { data quota) } \\
\text { - Online platforms } \\
\text { (Offline) } \\
\text { - Procurement and } \\
\text { repair of furniture } \\
\text { and study rooms } \\
\text { - Teachers and } \\
\text { educators (digital } \\
\text { learning skills) }\end{array}$ & & $\begin{array}{l}\text { Channels } \\
\text { (Online) } \\
\text { - WhatsApp, } \\
\text { Facebook, } \\
\text { Instagram, and } \\
\text { YouTube } \\
\text { (Offline) } \\
\text { - Word of mouth, } \\
\text { advertisements, } \\
\text { banners, } \\
\text { brochures, and } \\
\text { business cards }\end{array}$ & \\
\hline \multicolumn{2}{|c|}{$\begin{array}{l}\text { Cost Structure } \\
\text { - Salaries of teachers and educators } \\
\text { - School maintenance costs } \\
\text { - Student activity fees } \\
\text { - Teacher training costs } \\
\text { - Marketing costs }\end{array}$} & \multicolumn{3}{|c|}{$\begin{array}{l}\text { Revenue Streams } \\
\text { - Tuition fee } \\
\text { - BOS fund } \\
\text { - Fixed assistance }\end{array}$} \\
\hline
\end{tabular}

Figure 4 - A new business model canvas of SDS Kartini

c) Improvement of value propositions. This element is in the quadrant with high importance and performance. The value to be improved is to add lessons to support the curriculum or local content to enhance the quality of schools and use various online learning platforms during the COVID-19 Pandemic. The new value proposition consists of a learning process according to the curriculum and providing supporting lessons such as general skills and foreign languages; character education, religion, and abilities; guidance and consultation for students in need; and online learning using a variety of platforms.

d) Improvement of key partners. Elements of key partners have a high level of importance and performance. The main partners currently working with SDS Kartini are the Government, the Kartini Medan Foundation, donors, teachers, educators, and parents. SDS Kartini can increase collaboration with parents, alumni, and government institutions; those not yet partners of SDS Kartini in the business model are alumni. SDS Kartini can establish relationships with alumni to assist and support activities in both academic and non-academic fields. This element improves by adding alumni as leading partners of SDS Kartini.

e) Improvement of key activities. This element is also included in the category of high importance and performance. Changes to this element affect the channels, key partners, and key resources. Activities that need to be developed in this element are marketing activities and activities with alumni. Marketing activities can also optimize the utilization and use of information technology in marketing activities to be more effective. Activities with alumni align 
expanding and increasing collaboration with parents, alumni, and government agencies. Activities that can carry out are holding annual routine activities such as competitions or social services involving alumni. In addition, based on developing the competence of teachers and educators in digital learning, teacher and educator training activities need to be designed to improve digital learning training.

f) Improvement of cost structure. This element is the only element in the category of low importance and performance. Although the respondent has no interest in this element, this element is quite crucial for SDS Kartini. The cost structure also changes based on channel and key activities. The existence of marketing activities adds to the costs incurred by SDS Kartini. The difference in this element is the existence of marketing costs. Although experiencing an increased cost structure, SDS Kartini can carry out the activity plan and school budget. SDS Kartini's spending remains under control.

Improvements and developments in channel elements and key resources affect changes to other elements. However, customer relationships, revenue streams, and customer segments are not changed because these elements are in quadrant IV, with a high level of performance with low importance. There is no improvement and development on these elements.

\section{CONCLUSION}

The business model that SDS Kartini is currently running has been identified through the business model canvas. Business model evaluation determines business model improvement priorities using performance-interest analysis. The research results show that the main channel and resource elements focus on improvement in quadrant I. The design of the new business model resulted from the priority to improve the main resource channels and elements. Channel improvement, namely developing online and offline marketing media and adding key resources, adding online and offline school facilities, and increasing the ability of teachers and educators in digital learning. Improvements to these elements affect changes to other elements. However, customer relationships, revenue streams, and customer segments are not developed because they are in the high-performance and low-importance quadrant.

\section{REFERENCES}

1. Alawiyah, F. (2017). Standar Nasional Pendidikan Dasar dan Menengah. Aspirasi, 8(1), 81-92.

2. Amirullah. (2015). Metode Penelitian Manajemen. Bayumedia Publishing Malang.

3. Badan Pusat Statistik. (2020). Potret Pendidikan Indonesia Statistik Pendidikan. In Jakarta: Badan Pusat Statistik.

4. Fitriana, V., \& Triwiyanto, T. (2016). Strategi Yayasan untuk Menarik Minat Orang Tua dalam Menyekolahkan Anaknya. Manajemen Pendidikan, 25(2), 224-232.

5. Gazali, M. (2013). Optimalisasi Peran Lembaga Pendidikan Untuk Mencerdaskan Bangsa. Jurnal Al-Ta'dib, 6(1), 126-136.

6. Hardani, Andriani, H., Ustiawaty, J., Utami, E. F., Istiqomah, R. R., Fardani, R. A., Sukmana, D. J., \& Nur Hikmatul Auliya. (2020). Metode Penelitian: Kualitatif \& Kuantitatif (Issue March). Pustaka IImu.

7. Kementerian Kesehatan. (2020). Hindari Lansia dari COVID 19.

8. Kementerian Pendidikan dan Kebudayaan. (2021). Statistik Pendidikan.

9. Marini, A. (2016). Manajemen Pendidikan: Teori dan Aplikasinya. In PT Rineka Cipta. Jakarta. Penerbit Ombak.

10. Martilla, J. A., \& James, J. C. (1977). Importance-Performance Analysis: An easily applied technique for measuring attribute importance and performance can further the development of effective marketing programs. Journal of Marketing, 41(1), 77-79.

11. Matzler, K., Bailom, F., Hinterhuber, H. H., Renzl, B., \& Pichler, J. (2004). The asymmetric relationship between attribute-level performance and overall customer satisfaction: A reconsideration of the importance-performance analysis. Industrial 
Marketing Management, 33(4), 271-277.

12. Nielsen, C., \& Lund, M. (2018). An Introduction to Business Models. SSRN Electronic Journal.

13. Osterwalder, A., \& Pigneur, Y. (2013). Business Model Generation. John Wiley \& Sons.

14. Putri, R. S., Purwanto, A., Pramono, R., Asbari, M., Wijayanti, L. M., \& Hyun, C. C. (2020). Impact of the COVID-19 Pandemic on online home learning: An explorative study of primary schools in Indonesia. International Journal of Advanced Science and Technology, 29(5), 4809-4818.

15. Sari, R. P., Tusyantari, N. B., \& Suswandari, M. (2021). Dampak Pembelajaran Daring Bagi Siswa Sekolah Dasar Selama Covid-19. Prima Magistra: Jurnal Ilmiah Kependidikan, 2(1), 9-15.

16. Slávik, Š., \& Bednár, R. (2014). Analysis of Business Models. Journal of Competitiveness, 6(4), 19-40.

17. Supranto, J. (2001). Pengukuran Tingkat Kepuasan Pelanggan. PT. Rineka Cipta.

18. Teece, D. J. (2010). Business models, business strategy and innovation. Long Range Planning, 43(2-3), 172-194.

19. Viali, A. F., Rifin, A., \& Saptono, T. (2018). Strategi Pengembangan Bisnis Cargo PT. Garuda Indonesia, TBK dengan Pendekatan Business Model Canvas. Jurnal Aplikasi Manajemen Dan Bisnis, 4(3), 474-485.

20. Widyastuti, R. S., Fahmi, I., \& Maulana, A. (2019). Effect of Adding New Products on a Company's Business Model: a Case Study in Indonesia. Russian Journal of Agricultural and Socio-Economic Sciences, 96(12), 82-91. 